\section{Screening for acromegaly in adult patients not reporting enlargement of the extremities, but with arterial hypertension associated with another comorbidity of the disease}

\author{
Rastreamento de acromegalia em pacientes adultos não \\ relatando crescimento de extremidades, mas com hipertensão \\ arterial associada a outra comorbidade da doença
}

Pedro Weslley Rosario',2, Maria Regina Calsolari²

\begin{abstract}
Objective: To determine the value of acromegaly screening in adult patients not reporting enlargement of the extremities, but who present arterial hypertension associated with at least one other comorbidity of the disease. Subjects and methods: Patients seen by general practitioners at primary health care units were evaluated. Among the patients without extremity enlargement, those with recently diagnosed arterial hypertension associated with at least one other comorbidity were selected. Results: A total of 1,209 patients were submitted to laboratory investigation. Elevated IGF-1 was observed in 22 patients. Eighteen patients had adequate suppression of growth hormone (GH). No GH suppression was observed in four women with confirmed elevated IGF-1. In the latter, IGF-1 and nadir GH were only slightly elevated, magnetic resonance showed a normal pituitary, and chest and abdominal computed tomography revealed no tumor, and no intervention was performed. Conclusion: In patients with arterial hypertension without known pituitary disease, acromegaly is unlikely in the absence of enlargement of the extremities. Arq Bras Endocrinol Metab. 2014;58(8):807-11
\end{abstract}

\section{Keywords}

Acromegaly; screening; arterial hypertension; enlargement of the extremities

\section{RESUMO}

Objetivo: Determinar o valor do rastreamento de acromegalia em pacientes adultos sem aumento de extremidades, mas com hipertensão arterial associada a pelo menos uma outra comorbidade da doença. Sujeitos e métodos: Pacientes vistos por clínicos em unidades primárias de saúde foram avaliados. Entre pacientes sem aumento de extremidades, aqueles com hipertensão arterial diagnosticada recentemente e associada a pelo menos uma outra comorbidade foram selecionados. Resultados: Um total de 1.209 pacientes foi submetido à investigação laboratorial. IGF-1 foi elevado em 22 pacientes. Dezoito pacientes apresentavam supressão adequada do hormônio do crescimento $(\mathrm{GH})$. Ausência de supressão do $\mathrm{GH}$ foi vista em quatro mulheres com IGF-1 repetidamente elevado. Nestas, IGF-1 e nadir do GH foram apenas discretamente aumentados, ressonância magnética revelou hipófise normal, tomografia computadorizada de tórax e abdome não revelaram tumor, e nenhuma intervenção foi realizada. Conclusão: Em pacientes com hipertensão arterial sem doença hipofisária conhecida, acromegalia é improvável na ausência de aumento de extremidades. Arq Bras Endocrinol Metab. 2014;58(8):807-11

\section{Descritores}

Acromegalia; rastreamento; hipertensão arterial; aumento de extremidades
1 Postgraduation Program, Santa Casa de Belo Horizonte, Belo Horizonte, MG, Brazil ${ }^{2}$ Neuroendocrinology Department, Santa Casa de Belo Horizonte, Belo Horizonte, MG, Brazil

Correspondence to: Pedro Weslley Rosario Instituto de Ensino e Pesquisa, Santa Casa de Belo Horizonte Rua Domingos Vieira, 590 30150-240 - Belo Horizonte, MG, Brazil

pedrowsrosario@gmail.com

Received on Feb/27/2014 Accepted on July/1/2014

DOI: 10.1590/0004-2730000003314 


\section{INTRODUCTION}

A cromegaly generally has an insidious onset and its prevalence may be underestimated (1-3). If untreated, the hypersecretion of growth hormone $(\mathrm{GH})$ is associated with clinical complications and increased mortality $(4,5)$. In contrast, when acromegaly is diagnosed and treated adequately; tumor control, control of hormone secretion, prevention of the onset of complications, and improvement of existing comorbidities are possible in most patients (4-7). The importance of an early diagnosis is therefore unquestionable.

However, since acromegaly is a rare disease, the establishment of strategies designed to increase the diagnosis and to permit early detection in a rational and cost-effective manner is a challenge (3). Agreement regarding the need to investigate hypersecretion of $\mathrm{GH}$ exists for patients with a typical phenotype or imaging results compatible with pituitary adenoma (8). Except for these cases, there are no objective recommendations as to which patients should be evaluated for acromegaly (9-17), and the "clinical suspicion" is subject to the personal impression of each physician, which is influenced by academic background, degree of suspicion, experience with the disease, and motivation to diagnose it. In an attempt to encourage early detection, some authors and guidelines recommend acromegaly to be investigated in subjects with two or more comorbidities associated with the disease $(18,19)$. Considering its high prevalence in the general population, arterial hypertension is one of these comorbidities that would be interesting to study.

The objective of this study was to determine the value of acromegaly screening by serum IGF-1 measurement in adult patients without known pituitary disease and not reporting enlargement of the extremities, but who present arterial hypertension associated with at least one other comorbidity of the disease $(18,19)$.

\section{SUBJECTS AND METHODS}

The study and its respective protocol were approved by the Ethics Committee of our institution and informed consent was obtained from all subjects. The study was prospective.

Among the patients seen by general practitioners between July and December 2010 at the 9 primary health care units of the city of Belo Horizonte (one per Sanitary District), subjects of both genders ranging in age from 18 to 70 years without known pituitary disease, and excluding pregnant women, were initially evaluated $(n=17,000)$. The medical records of these patients were analyzed and personal interviews were conducted, including the application of a questionnaire for the detection of extremity enlargement (3). The items of the questionnaire were: Has your shoe size increased over the last 5 years? Did you have to change your wedding ring or ring over the last 5 years because it became tight? The interviews were conducted and the questionnaires were applied by nursing students enrolled in the School of Nursing (3).

One hundred seventy nine patients responded positively to at least one of the items of the questionnaire and the results of these patients have been published previously (3). Among the 16,821 patients who responded negatively to two items of the questionnaire, 1,806 subjects with recently diagnosed ( $<5$ years) arterial hypertension requiring antihypertensive medication, associated with at least one other comorbidity of acromegaly, were subsequently selected for this study. These comorbidities were $(18,19)$ : (i) nonspecific chronic headache (for example, migraine and hypertensive headache were not considered); (ii) generalized and persistent excessive sweating; (iii) diffuse arthralgias associated with some radiologic alteration (20) in the absence of known rheumatological disease (reported by the patient, suspected, or confirmed in the medical record); (iv) chronic fatigue not explained by any other underlying disease (among the diagnoses reported by the patient or present in the medical record); (v) bilateral paresthesias (Carpal tunnel syndrome); (vi) recently diagnosed diabetes mellitus.

Because of the possibility of interference with laboratory assessment, patients with known kidney or liver disease, patients with anorexia nervosa, patients presenting weight loss $>5 \%$ in the last 3 months and $\mathrm{BMI}<18.5 \mathrm{~kg} / \mathrm{m}^{2}$, or women receiving oral estrogens were excluded. The remaining 1,209 patients comprised the final sample (Figure 1).

Serum IGF-1 was measured in all patients included in study. Acromegaly was ruled out if serum IGF-1 was normal for sex and age. When IGF-1 levels were elevated, a new measurement was obtained and combined with the measurement of $\mathrm{GH}$ during an oral glucose tolerance test (OGTT) (GH before and 30, 60, 90 and $120 \mathrm{~min}$ after the oral administration of $75 \mathrm{~g}$ anhydrous glucose). Patients with persistently elevated IGF-1 associated with nadir GH $\geq 0.4 \mu \mathrm{g} / \mathrm{L}$ $(4,5,9,10,12,15,16,19,21)$ were submitted to magnetic 


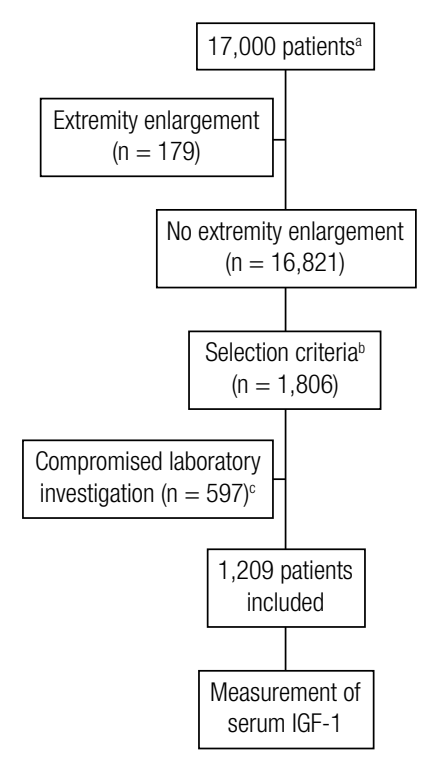

a Patients seen by general practitioners at primary health care units, ranging in age from 18 to 70 years, without known pituitary disease and excluding pregnant women.

${ }^{b}$ Patients with recently diagnosed $(<5$ years) arterial hypertension requiring antihypertensive medication, associated with at least one other comorbidity $(18,19)$.

"Patients with known kidney or liver disease, patients with anorexia nervosa, patients with weight loss $>5 \%$ in the last 3 months and $\mathrm{BMl}<18.5 \mathrm{~kg} / \mathrm{m}^{2}$, or women receiving oral estrogens.

Figure 1. Selection of patients included in the study.

resonance imaging (MRI) of the pituitary using gadolinium as contrast agent. The samples were collected in the morning after an approximately 10 -h fast, with the subject resting for $20 \mathrm{~min}$ before and during the OGTT.

GH was measured with a chemiluminescence assay (Immulite, Diagnostic Products Corporation, Los Angeles, CA) with an analytical sensitivity $\leq 0.05 \mu \mathrm{g} / \mathrm{L}$. The standard provided by the kit was calibrated against the World Health Organization (WHO) $2^{\text {nd }}$ International Standard (IS) 98/574. The results are expressed as $\mu \mathrm{g} / \mathrm{L}$. IGF- I was also measured with a chemiluminescent assay (Immulite 2000, Diagnostic Products Corporation, Los Angeles, CA) with an analytical sensitivity of $25 \mu \mathrm{g} / \mathrm{L}$ using standards calibrated against the WHO IS $87 / 518$ preparation, and previously established reference values stratified by sex and age based on a sample of 1,000 subjects rigorously selected in the same town where the study was conducted (22).

\section{RESULTS}

Among the 1,209 patients submitted to laboratory investigation of acromegaly, 613 were women and 606 were men. Patient age ranged from 20 to 70 years (me- dian 51 years). In addition to arterial hypertension (inclusion criterion), the comorbidities $(18,19)$ detected in the patients are shown in table 1. Elevated serum IGF-1 levels for sex and age were observed in $22 \mathrm{pa}-$ tients. When the measurement was repeated, three patients presented normal IGF-1 and adequate suppression of GH in the OGTT. Fifteen of the 19 patients with persistently elevated IGF-l had adequate suppres-

Table 1. Comorbidities $(18,19)$, in addition to arterial hypertension (inclusion criterion), detected in the 1,209 patients included in the study

\begin{tabular}{lc}
\hline Comorbidity & Number of patients \\
\hline Chronic headache & $675(55.8 \%)$ \\
Diabetes mellitus & $331(27.3 \%)$ \\
Chronic fatigue & $278(23 \%)$ \\
Diffuse arthralgias & $274(22.6 \%)$ \\
Paresthesias (Carpal tunnel syndrome) & $263(21.7 \%)$ \\
Excessive sweating & $150(12.4 \%)$ \\
\hline Number of comorbidities & \\
\hline 1 & $615(50.8 \%)$ \\
2 & $480(39.7 \%)$ \\
$\geq 3$ & $124(10.2 \%)$ \\
\hline
\end{tabular}

Table 2. Results of the 19 patients with persistently elevated IGF-1

\begin{tabular}{|c|c|c|c|c|c|}
\hline Patient & Sex & $\begin{array}{c}\text { Age } \\
\text { (years) }\end{array}$ & $\begin{array}{c}\text { IGF-1 } \\
\text { (x ULN) }\end{array}$ & $\begin{array}{c}\text { Nadir } \\
\text { GH } \\
(\mu \mathrm{g} / \mathrm{L})\end{array}$ & $\begin{array}{c}\text { Number of } \\
\text { comorbidities } \\
\text { (in addition to } \\
\text { arterial } \\
\text { hypertension) }\end{array}$ \\
\hline 1 & Male & 65 & 1.2 & 0.1 & 1 \\
\hline 2 & Male & 61 & 1.15 & 0.1 & 1 \\
\hline 3 & Male & 44 & 1.22 & 0.15 & 2 \\
\hline 4 & Male & 39 & 1.08 & 0.18 & 2 \\
\hline 5 & Male & 37 & 1.1 & 0.2 & 1 \\
\hline 6 & Male & 53 & 1.05 & 0.22 & 1 \\
\hline 7 & Male & 65 & 1.2 & 0.2 & 2 \\
\hline 8 & Male & 48 & 1.05 & 0.2 & 1 \\
\hline 9 & Male & 35 & 1.1 & 0.16 & 2 \\
\hline 10 & Female & 61 & 1.08 & 0.18 & 1 \\
\hline 11 & Female & 52 & 1.15 & 0.2 & 2 \\
\hline 12 & Female & 50 & 1.08 & 0.2 & 1 \\
\hline 13 & Female & 45 & 1.21 & 0.24 & 2 \\
\hline 14 & Female & 36 & 1.05 & 0.28 & 1 \\
\hline 15 & Female & 60 & 1.1 & 0.3 & 1 \\
\hline 16 & Female & 42 & 1.07 & 0.5 & 2 \\
\hline 17 & Female & 58 & 1.12 & 0.56 & 3 \\
\hline 18 & Female & 35 & 1.28 & 0.68 & 2 \\
\hline 19 & Female & 38 & 1.15 & 0.85 & 1 \\
\hline
\end{tabular}

ULN: upper limit of normal. 
sion of GH in the OGTT (patients 1-15 in Table 2). No GH suppression in the OGTT was observed in four women with confirmed elevated IGF-1 (patients 16-19 in Table 2). Since serum IGF-1 and nadir GH were only slightly elevated, MRI showed a normal pituitary and chest and abdominal contrast-enhanced computed tomography revealed no tumor, no intervention was performed. These four patients continue under followup (clinical assessment and measurement of IGF-l at intervals of 6 months), with the absence of symptom progression and observation of stable IGF-1 levels in three and subsequent spontaneous and persistent normalization of IGF-1 in one patient (patient 16 in Table 2). The time of follow-up until now is 3 years.

\section{DISCUSSION}

The currently available therapies (surgery, somatostatin analogs, GH antagonists, dopamine agonists, radiotherapy) permit the control and occasional cure of tumors and hormone hypersecretion, as well as the improvement and even reversal of comorbidities, in most patients with acromegaly (4-7). This chance is even higher when the disease is detected early. The fact that acromegaly is underdiagnosed (1-3) or diagnosed late (23) continues to be the problem. Most patients report that they have sought medical care due to manifestations of the disease before the diagnosis was finally suspected $(23,24)$. Therefore, the problem does not seem to be the lack of seeking medical care on the part of patients, but rather the lack of familiarity of health professionals with the manifestations of acromegaly, who do not remember this hypothesis when treating patients with suspicious signs and/or symptoms (3). This fact is supported by the observation that, even in screening studies, the cases detected already exhibit an exuberant phenotype, but the disease had not been suspected by the physicians (1-3), probably due to the rarity of the condition.

Objective recommendations as to which subjects should be investigated for acromegaly may improve detection of the disease. This is the case of patients with imaging findings compatible with pituitary adenoma (8). Subjects with a "suspicious phenotype" are also recommended for investigation, but there is no objective definition of this phenotype (9-17), which is left to the personal impression of each physician.

Enlargement of the extremities is an early and almost universal manifestation of acromegaly (23-29). In fact, a previous study suggested that the presence of this finding evaluated by two simple questions is an objective, simple and cost-effective method to define a "suspicious phenotype" (3). The present study determined whether this manifestation would be sufficiently sensitive to detect acromegaly in patients without a known pituitary tumor which, if confirmed, would support the validity of this parameter (growth of the extremities) as a criterion to indicate investigation for acromegaly. At the same time, this criterion was compared to the recommendation proposed by other authors, i.e., the investigation of subjects with two or more comorbidities $(18,19)$. In view of its high prevalence in the general population, arterial hypertension is one comorbidity that would be interesting to study.

We observed no case of acromegaly among 1,209 adult patients without a known pituitary tumor who did not report growth of the extremities, although they presented two or more comorbidities [arterial hypertension associated with at least one other comorbidity] as proposed by some authors $(18,19)$. It should be noted that additional criteria were adopted to increase the specificity of these manifestations. This result highlights the importance of growth of the extremities while, at the same time, weakens the cost-effectiveness of investigating acromegaly in subjects without a known pituitary tumor in the absence of that manifestation.

We cannot rule out acromegaly in patients with elevated serum IGF- 1 based on adequate normative values (22) in two measurements, in the absence of pregnancy, hyperthyroidism and puberty, and accompanied by the lack of GH suppression in the OGTT. However, we believe that the disease is unlikely in the four patients of our series with this finding considering the presence of only slightly elevated serum IGF-1 and nadir GH and the absence of a tumor on MRI. In fact, cases of acromegaly with GH suppression in the OGTT exhibited apparent adenoma on MRI (27-32). Furthermore, ectopic production of GHRH is unlikely in the presence of the biochemical findings cited, normal MRI (no hyperplasia), and absence of a tumor on chest and abdominal CT scans (33). Corroborating the absence of disease, the four patients continue without symptom progression and with stable IGF-1 levels (no intervention). Cases of patients with unexplainable elevated IGF- 1 and without acromegaly have been reported by other authors $(32,34)$.

The results of this study indicate that acromegaly is unlikely in patients with arterial hypertension and without known pituitary disease in the absence of growth 
of the extremities and that this finding can be used to select patients who should be submitted to investigation for $\mathrm{GH}$ hypersecretion (3).

Disclosure: no potential conflict of interest relevant to this article was reported.

\section{REFERENCES}

1. Schneider HJ, Sievers C, Saller B, Wittchen HU, Stalla GK. High prevalence of biochemical acromegaly in primary care patients with elevated IGF-1 levels. Clin Endocrinol (Oxf). 2008;69:432-5.

2. Rosario PW. Frequency of acromegaly in adults with diabetes or glucose intolerance and estimated prevalence in the general population. Pituitary. 2011;14:217-21.

3. Rosario PW, Calsolari MR. Screening for acromegaly by application of a simple questionnaire evaluating the enlargement of extremities in adult patients seen at primary health care units. Pituitary. 2012;15:179-83.

4. Melmed S, Colao A, Barkan A, Molitch M, Grossman AB, Kleinberg D, et al.; Acromegaly Consensus Group. Guidelines for acromegaly management: an update. J Clin Endocrinol Metab. 2009;94:1509-17.

5. Melmed S, Casanueva FF, Klibanski A, Bronstein MD, Chanson P, Lamberts SW, et al. A consensus on the diagnosis and treatment of acromegaly complications. Pituitary. 2013;16:294-302.

6. Giustina A, Bronstein MD, Casanueva FF, Chanson P, Ghigo E, Ho $\mathrm{KK}$, et al. Current management practices for acromegaly: an international survey. Pituitary. 2011;14:125-33.

7. Giustina A, Chanson P, Kleinberg D, Bronstein MD, Clemmons DR, Klibanski A, et al. Expert consensus document: a consensus on the medical treatment of acromegaly. Nat Rev Endocrinol. 2014;10:243-8.

8. Freda PU, Beckers AM, Katznelson L, Molitch ME, Montori VM, Post $K D$, et al. Pituitary incidentaloma: an Endocrine Society clinical practice guideline. J Clin Endocrinol Metab. 2011;96:894-904.

9. Melmed S. Medical progress: acromegaly. N Engl J Med. 2006;355:2558-73.

10. Arellano $S$, Aguilar P, Domínguez B, Espinosa-de-Los-Monteros AL, González Virla B, Sosa E, et al. Segundo Consenso Nacional de Acromegalia: recomendaciones para su diagnóstico, tratamiento y seguimiento. Rev Endocrinol Nutr. 2007;15:S7-S16.

11. Giustina A, Barkan A, Chanson P, Grossman A, Hoffman A, Ghigo $E$, et al. Guidelines for the treatment of growth hormone excess and growth hormone deficiency in adults. J Endocrinol Invest. 2008;31:820-38.

12. Chanson P, Bertherat J, Beckers A, Bihan H, Brue T, Caron P, et al. French consensus on the management of acromegaly. Ann Endocrinol (Paris). 2009;70:92-106.

13. Cozzi R, Baldelli R, Colao A, Lasio G, Zini M, Attanasio R. AME Position Statement on clinical management of acromegaly. J Endocrinol Invest. 2009;32:2-25.

14. Barkan A, Bronstein MD, Bruno OD, Cob A, Espinosa-de-los-Monteros AL, Gadelha MR, et al. Management of acromegaly in Latin America: expert panel recommendations. Pituitary. 2010;13:168-75.

15. Vieira Neto L, Abucham J, Araujo LA, Boguszewski CL, Bronstein MD, Czepielewski M, et al. Recommendations of Neuroendocrinology Department from Brazilian Society of Endocrinology and Metabolism for diagnosis and treatment of acromegaly in Brazil. Arq Bras Endocrinol Metabol. 2011;55:91-105.
16. Cordido F, García Arnés JA, Marazuela Aspiroz M, Torres Vela E. Practical guidelines for diagnosis and treatment of acromegaly. Endocrinol Nutr. 2013;60:457.e1-457.e15.

17. Bronstein MD, Bruno OD, Abreu A, Mangupli R, Mercado M. A practical approach to acromegaly management in Latin America. Pituitary. 2014;17 (suppl 1):30-5.

18. Ezzat $\mathrm{S}$, Serri $\mathrm{O}$, Chik $\mathrm{CL}$, Johnson MD, Beauregard $\mathrm{H}$, Marcovitz $\mathrm{S}$, et al. Canadian consensus guidelines for the diagnosis and management of acromegaly. Clin Invest Med. 2006;29:29-39.

19. Katznelson L, Atkinson JL, Cook DM, Ezzat SZ, Hamrahian AH, Miller KK. American Association of Clinical Endocrinologists medical guidelines for clinical practice for the diagnosis and treatment of acromegaly - 2011 update. Endocr Pract. 2011;17:1-44.

20. Killinger Z, Payer J, Lazúrová I, Imrich R, Homérová Z, Kužma $M$, et al. Arthropathy in acromegaly. Rheum Dis Clin North Am. 2010;36:713-20.

21. Giustina $A$, Chanson $P$, Bronstein MD, Klibanski $A$, Lamberts $S$, Casanueva FF, et al. A consensus on criteria for cure of acromegaly. J Clin Endocrinol Metab. 2010;95:3141-8.

22. Rosario PW. Normal values of serum IGF-1 in adults: results from a Brazilian population. Arq Bras Endocrinol Metabol. 2010;54:477-81.

23. ReidTJ, Post KD, Bruce JN, Nabi Kanibir M, Reyes-Vidal CM, Freda PU. Features at diagnosis of 324 patients with acromegaly did not change from 1981 to 2006; acromegaly remains under-recognized and under-diagnosed. Clin Endocrinol (Oxf). 2010;72:203-8.

24. Nachtigall L, Delgado A, Swearingen B, Lee H, Zerikly R, Klibanski $A$. Changing patterns in diagnosis and therapy of acromegaly over two decades. J Clin Endocrinol Metab. 2008;93:2035-41.

25. Molitch ME. Clinical manifestations of acromegaly. Endocrinol Metabol Clin N Am. 1992;21:597-614.

26. Ezzat S, Forster MJ, Berchtold P. Acromegaly: clinical and biochemical features in 500 patients. Medicine. 1994;73:233-40.

27. Mercado M, Espinosa-de-Los-Monteros AL, Sosa E. Clinicalbiochemical correlations in acromegaly at diagnosis and the real prevalence of biochemically discordant disease. Horm Res. 2004;62:293-9.

28. Dimaraki EV, Jaffe CA, DeMott-Friberg R, Chandler WF, Barkan AL. Acromegaly with apparently normal GH secretion: implications for diagnosis and follow-up. J Clin Endocrinol Metab. 2002;87:3537-42.

29. Freda PU, Reyes CM, Nuruzzaman AT, Sundeen RE, Bruce JN. Basal and glucose-suppressed GH levels less than 1 microg/ $L$ in newly diagnosed acromegaly. Pituitary. 2003;6:175-80.

30. Petersenn S, Buchfelder M, Gerbert B, Franz H, Quabbe HJ, Schulte $\mathrm{HM}$, et al. Age and sex as predictors of biochemical activity in acromegaly: analysis of 1485 patients from the German Acromegaly Register. Clin Endocrinol (Oxf). 2009;71:400-5.

31. Ribeiro-Oliveira A Jr, Faje AT, Barkan AL. Limited utility of oral glucose tolerance test in biochemically active acromegaly. Eur $\mathrm{J}$ Endocrinol. 2011;164:17-22.

32. Subbarayan SK, Fleseriu M, Gordon MB, Brzana JA, Kennedy L, Faiman $C$, et al. Serum IGF-1 in the diagnosis of acromegaly and the profile of patients with elevated IGF-1 but normal glucosesuppressed growth hormone. Endocr Pract. 2012;18:817-25.

33. Garby L, Caron P, Claustrat F, Chanson P, Tabarin A, Rohmer V, et al. Clinical characteristics and outcome of acromegaly induced by ectopic secretion of growth hormone-releasing hormone (GHRH): a French nationwide series of 21 cases. J Clin Endocrinol Metab. 2012;97:2093-104.

34. Bancos I, Algeciras-Schimnich A, Grebe SK, Donato LJ, Nippol$\mathrm{dt} T \mathrm{~T}$, Erickson D. Evaluation of variables influencing the measurement of insulin like growth factor-1 (IGF-1). Endocr Pract. 2014;20:421-6. 